\title{
Efficiency of Sorbents Application for the Decrease of the Residual Content of Oil Products in the Industrial Waste
}

\author{
Svetlana Tarasova ${ }^{1 *}$, Elena Gaevaya ${ }^{1}$, Anastasia Bytsko' \\ 1 Federal State Budget Educational Institution of Higher Education «Industrial University of Tyumen», \\ Volodarskogo 38, 652000 Tyumen, Russia \\ *Corresponding author's e-mail: tarasovass@tyuiu.ru
}

\begin{abstract}
Well drilling involves the formation of the bore mud in a form of drilled solids with waste drilling mud, containing oil products in its structure. Nowadays, the widely used methods such as thermal, physical and biological ones cannot be considered as complex approach to the solution of the problem of the oil refinery wastes handling. Introduction of the peat and natural mineral sorbents into the bore mud allows decreasing the residual content of the oil products, and, thus, decreasing the level of negative influence on the environment. On the basis of the conducted studies, it was revealed that different norms of sorbents and peat introduction into the bore mud decreased the concentration of oil products equally well; therefore, the recommended dosage of sorbents and peat at the low initial values of oil products can be $3-5 \%$. When introducing glauconite in a form of flour and grain there it noted that the size of grain particles of the sorbent influenced insignificantly the decrease of oil products concentration in the bore mud. The use of natural mineral sorbents and peat favorably influences the development of plants. At the same time, the formation of viable phytocenosis with high value of phytomass of vegetative over-ground sprouts takes place.
\end{abstract}

Keywords: bore mud, oil products, sorbents, peat, sorption capacity, cultures-phytomeliorants.

\section{INTRODUCTION}

The development of the oil and gas industry is accompanied by the increase of the manmade pressures on the environment. During the drilling of wells, the direct pollution of soils as well as underground and ground waters adjoining to the oil deposits, takes place. Especially strong negative influence on the objects of environment is made by the drilling cuttings formed in the process of oil and gas wells construction. These drilling cuttings include: bore wastewaters, waste drilling flushing, drilled rock or bore muds [Uzbekov et al. 2003, Bulatov et al. 1997]. As a result of the drilling cuttings introduction on the soil surface, the destruction of soil-vegetable cover takes place, as well as decrease of its microbiological activity, especially under the conditions of northern territories [Ryazanov 2005].
The bore flushing is used for the extracting of the rotted rock. This bore flushing is necessary for the removal of the detrital product of the rocks from the bottom, cooling down of rock cutting tools, prevention and liquidation of the complications, opening of productive layers. The service water is used additionally for the cleaning of mud screen nettings, washing of threaded connections of the drilling pipes and also when washing the equipment and production sites [Vadetsky 2003]. The drilling agents applied in the process of drilling can be changed during the hole drilling for every production string and have different compositions. The use of different components included into the content of drilling agent influences the properties of the drilled solids, which transform into the bore mud in the drilling process [Ryadinsky and Deneko 2004].

The bore mud, formed during the drilling using hydrocarbon-based drilling agents, is soft 
plastic paste-like mass of black color. Bore muds have negative water-physical properties: low aeration, poor filtration ability, etc. [Belov et al. 1991]. The ability of bore mud to absorb pollutants from the drilling agent depends to a great extent on the content of the smallest particles in it, mainly colloidal. It depends on the content of physical clay $(<0.01 \mathrm{~mm})$, in particular the silt fraction $(<0.004 \mathrm{~mm})$. The density of bore mud depends on the density of the drilling agent and cuttings; for Western Siberia, the density of bore mud varies from 1.3 to $2.2 \mathrm{~g} / \mathrm{cm}^{3}$ [Golubev and Soromotin 2010].

Due to the lack of studies on the influence on the hydrocarbon-based bore muds on the components of the environment, it is necessary to determine the norms of introduction of peat and natural mineral sorbents which allow decreasing the oil products content in the wastes and also the degree of negative influence on the environment.

\section{MATERIAL AND METHODS}

The bore mud formed in the process of well drilling using the hydrocarbon base solution represents the solid phase of the drilling wastes. During the scientific studies, mechanical mix of the bore mud and natural mineral sorbents (finely dispersed and coarse aggregate state) was performed. Additionally, the residual content of oil products in the process of utilization of the studied waste was determined. The following materials were used as the sorbents:

- peat - the decomposition product of dead parts of grassy, deciduous and coniferous plants, moss. It increases the acidity of the environment when added to the soil. This is the organic rock with sorption properties in relation to the oil products.

- glauconite - aqueous aluminosilicate of iron, silica and oxidizing enzyme in a form of small, rounded seed color of which varies from olive to dark green color. It has high sorption capacity in relation to heavy metals (up to $80 \%$ ), oil products and radionuclides. It has high capacity to pyridine and naphthanoic acids that allows using it as selective sorbent when cleaning the oil products from harmful impurities.

- zeolite - aqueous aluminosilicate of calcium and sodium with glassy or pearl shine. It has high sorption capacity but simultaneously it can desorb after some time, depending on the temperature and humidity.

The scientific research was carried out on the basis of the laboratory of the de-partment of Technosphere Safety; the determination of oil products was carried out using the fluorimetric method, based on the excitation of the electronic spectra of emission by the substance molecules under external UV irradiation and measuring the intensity of their photoluminescence.

In order to reduce the concentration of the oil products in the drill cuttings, natural mineral sorbents and peat were introduced in the amount of $3 \%, 5 \%, 7 \%, 10 \%, 15 \%, 20 \%, 25 \%$ of the volume of the studied waste.

During the phytotoxicity study, the main parameter of biotesting is seed germination. Germination is an indicator that is characterized by the number of seeds normally germinated over a certain period of time under certain optimal conditions of germination (except for the studied factor) with respect to the total number of seeds taken for germination, and is expressed as a percentage. We used boneless rump a phytoculture (seeding rate of $100 \mathrm{pcs}$. /vessel) [National Standard 12038-84. 2019].

\section{RESULTS}

The bore muds are characterized by the alkaline $\mathrm{pH}$ of environment, since the drilling agent includes calcium chloride (7-15\%). When determining the $\mathrm{pH}$ index in the bore mud, its value amounted to 7.31 units $\mathrm{pH}$, consequently, it indicates neutral environment. The content of the oil products in the bore mud made up $1800 \mathrm{mg} / \mathrm{kg}$.

Oil and oil products as the pollutants of bowels of the earth and environment are assessed according to the degree of toxicity and geochemical stability. The bore mud containing the oil products has a negative influence on the soil in the process of drilling. Penetrating into soil, the oil products change its physical and chemical properties, destroy soil structure, disperse its particles, as well as change the relation between the carbon and nitrogen [Kornev and Rybakov 2015, Ovchinnikov et al. 2013].

The research results of the introduction of natural mineral sorbent glauconite (in the form of cereals) in the bore mud are given in the Table 1. 
When introducing the natural mineral glauconite sorbent in a form of grain (particles size $d \leq 2 \mathrm{~mm}$ ), the least content of oil products was observed in different percentages of the bore mud amount. It was revealed that the decrease of the oil products concentration took place on the seventh day, the values varied from 61.17 to $79.33 \mathrm{mg} / \mathrm{kg}$. According to the data of studies, the oil products content in the samples decreased by 29 times after the introduction of sorbent. This indicates high absorptive qualities of glauconite.

The results of studies on the introduction of natural mineral sorbent glauconite (in the form of flour) in the bore mud are given in Table 2.

An analysis of the oil products content when the glauconite in the form of flour is introduced (particle size $d \leq 0.01 \mathrm{~mm}$ ), showed that the best indices were obtained on the 7th, 14th, 21st, 28th day of the study with $25 \%$ sorbent applied and varied from 56 to $48 \mathrm{mg} / \mathrm{kg}$. The aluminosilicate sorbents (glauconites) are highly porous formations, and this factor determines their sorption capacity. The smaller the particle size, the more efficient and significantly faster the sorbing of pollutants is.

The results of the study of peat adding in the bore mud are given in the Table 3 .

Owing to the features of the chemical content and structural organization of peat substance, it can be used for the solution of wide range of tasks of practical nature management, including liquidation of emergency oil and oil products spills in

Table 1. The results of determining of the residual content of oil products when introducing glauconite (grain)

\begin{tabular}{|c|c|c|c|c|}
\hline \multirow{2}{*}{$\begin{array}{c}\text { Number of introduced glauconite (grain) } \\
\text { in percentage relation of the bore mud }\end{array}$} & \multicolumn{4}{|c|}{ Residual content of oil products. mg/kg } \\
\cline { 2 - 5 } & On $7^{\text {th }}$ day & On $14^{\text {th }}$ day & On $21^{\text {st }}$ day & On $28^{\text {th }}$ day \\
\hline $3 \%$ & 79.33 & 67.00 & 66.50 & 66.00 \\
\hline $5 \%$ & 71.50 & 53.00 & 53.00 & 52.50 \\
\hline $7 \%$ & 61.17 & 54.50 & 55.00 & 54.50 \\
\hline $10 \%$ & 69.17 & 52.00 & 51.00 & 51.00 \\
\hline $15 \%$ & 69.00 & 51.00 & 50.50 & 50.00 \\
\hline $20 \%$ & 77.33 & 48.45 & 48.30 & 47.95 \\
\hline $25 \%$ & 65.67 & 47.20 & 47.30 & 47.30 \\
\hline
\end{tabular}

Table 2. The results of determining the residual content of oil products when making glauconite (flour)

\begin{tabular}{|c|c|c|c|c|}
\hline \multirow{2}{*}{$\begin{array}{c}\text { Amount of introduced glauconite (flour) } \\
\text { in the percentage ratio of the bore mud }\end{array}$} & \multicolumn{4}{|c|}{ The residual content of oil products. mg/kg } \\
\cline { 2 - 5 } & On $7^{\text {th }}$ day & On $14^{\text {th }}$ day & On $21^{\text {st }}$ day & On $28^{\text {th }}$ day \\
\hline $3 \%$ & 78.33 & 53.00 & 53.50 & 53.50 \\
\hline $5 \%$ & 77.17 & 57.00 & 56.00 & 56.00 \\
\hline $7 \%$ & 76.83 & 51.00 & 50.50 & 50.50 \\
\hline $10 \%$ & 78.50 & 50.00 & 49.95 & 49.40 \\
\hline $15 \%$ & 63.83 & 50.00 & 50.00 & 49.70 \\
\hline $20 \%$ & 63.67 & 49.15 & 49.10 & 48.85 \\
\hline $25 \%$ & $\mathbf{5 6 . 1 7}$ & $\mathbf{4 8 . 8 0}$ & $\mathbf{4 8 . 9 5}$ & $\mathbf{4 8 . 6 0}$ \\
\hline
\end{tabular}

Table 3. The results of the determining of the residual oil products content when adding peat

\begin{tabular}{|c|c|c|c|c|}
\hline \multirow{2}{*}{$\begin{array}{l}\text { Amount of introduced peat in } \\
\text { percentage ratio of the bore mud on the } \\
\text { hydrocarbon-based solution }\end{array}$} & \multicolumn{4}{|c|}{ The residual content of oil products. $\mathrm{mg} / \mathrm{kg}$} \\
\hline & On $7^{\text {th }}$ day & On $14^{\text {th }}$ day & On $21^{\text {st }}$ day & On $28^{\text {th }}$ day \\
\hline $3 \%$ & 73.67 & 53.00 & 52.50 & 52.00 \\
\hline $5 \%$ & 69.33 & 53.50 & 54.00 & 53.50 \\
\hline $7 \%$ & 68.67 & 49.25 & 49.60 & 49.85 \\
\hline $10 \%$ & 59.00 & 45.40 & 45.90 & 45.55 \\
\hline $15 \%$ & 54.33 & 46.20 & 45.35 & 45.65 \\
\hline $20 \%$ & 63.17 & 53.50 & 53.50 & 53.00 \\
\hline $25 \%$ & 61.67 & 52.50 & 53.00 & 54.00 \\
\hline
\end{tabular}


the soil; recultivation of soil contaminated with oil products [Gridin O.M. et al. 2000].

The obtained test data indicate that the sorption processes occurred with different intensities in all considered variants during the experiment. When peat was introduced from 10 to $15 \%$ into the bore mud, the lowest values of oil products were observed, and varied from $45.35 \mathrm{mg} / \mathrm{kg}$ to $54.33 \mathrm{mg} / \mathrm{kg}$. When $10 \%$ sorbent was introduced, the maximum decrease in the concentration of this element occurred on the 14th and 28th day of the study. The adsorbing properties of peat are stipulated by the presence of humic acids and lignin in its composition.

The results of the studies of zeolite adding in the bore mud are given in the Table 4 .

The efficiency of zeolites was assessed by the degree of oil hydrocarbons destruction. As the study results show, the concentration of oil products has decreased by $28 \%$. It was found out that the best indices were obtained on the 14th, 21 st, and 28th day of the study when introducing $25 \%$ of zeolite.

The introduction of hydrocarbon-based bore mud, additives in a form of the natural mineral sorbent or peat as the main additive provide a comprehensive normalization of the $\mathrm{pH}$ of the medium. Owing to the high sorption capacity of sorbents and peat, their use in hydrocarbon-based bore mud can reduce the content of oil products. The developed scheme for introducing the most effective sorbents and peat can minimize the risks of the anthropogenic load on the natural eco-systems. The presence of pollutants and toxins suppresses the growth and development of higher plants. When assessing the phytotoxicity of the transformed bore mud, the seeds of awnless brome were used as biotests. It is known that the resistance of a plant to adverse environmental factors depends on its age, and more precisely on the phase of individual development.

The germination of seeds is the most vulnerable stage of individual development of higher plants, when the minimal resistance to the unfavorable factors is observed, and, consequently, the maximal sensitivity to their influence. Thus, the plants in this phase represent the most attractive testing object and different parameters of germination during the carrying out of ecological experiments.

The results of studies of natural sorbents and peat introduction in the bore mud on the plantsphytoameliorants are given in the Table 5 .

In the control sample (bore mud), seed germination was $15 \%$ with a height of aboveground sprouts of $4.3 \mathrm{~cm}$ and a phytomass of

Table 4. Residual content of the oil products after introducing of zeolite

\begin{tabular}{|c|c|c|c|c|}
\hline \multirow{2}{*}{$\begin{array}{l}\text { Amount of introduced zeolite in the } \\
\text { percentage ratio of the bore mud }\end{array}$} & \multicolumn{4}{|c|}{ The residual content of oil products. mg/kg } \\
\hline & On $7^{\text {th }}$ day & On $14^{\text {th }}$ day & On $21^{\text {st }}$ day & On $28^{\text {th }}$ day \\
\hline $3 \%$ & 81.17 & 54.00 & 55.00 & 54.00 \\
\hline $5 \%$ & 67.83 & 50.50 & 49.70 & 49.80 \\
\hline $7 \%$ & 75.17 & 48.15 & 46.80 & 47.15 \\
\hline $10 \%$ & 56.33 & 51.00 & 51.00 & 50.00 \\
\hline $15 \%$ & 57.17 & 49.30 & 49.10 & 49.25 \\
\hline $20 \%$ & 55.83 & 48.80 & 49.05 & 49.00 \\
\hline $25 \%$ & 63.33 & 40.80 & 40.70 & 40.10 \\
\hline
\end{tabular}

Table 5. The results of studies of natural sorbents and peat introduction in the bore mud on the plants-phytoameliorants

\begin{tabular}{|c|l|c|c|c|c|c|}
\hline \multirow{2}{*}{$\begin{array}{c}\text { № } \\
\mathrm{n} / \mathrm{n}\end{array}$} & \multicolumn{1}{|c|}{ Variants } & $\begin{array}{c}\text { Bore mud } \\
\text { (control) }\end{array}$ & $\begin{array}{c}\text { Glauconite in a form of } \\
\text { grain (in an amount } \\
\text { of 15\% of the bore mud) }\end{array}$ & $\begin{array}{c}\text { Bore mud } \\
\text { (control) }\end{array}$ & $\begin{array}{c}\text { Peat (in an amount } \\
\text { of 15 \% of the bore } \\
\text { mud) }\end{array}$ & $\begin{array}{c}\text { Bore mud } \\
\text { (control) }\end{array}$ \\
\hline 1 & $\begin{array}{l}\text { Number of species. 100 } \\
\text { pcs. }\end{array}$ & 15 & 100 & 100 & 100 & 100 \\
\hline 2 & Viable state of plants & Weakened & Viable & Viable & Viable & Viable \\
\hline 3 & $\begin{array}{l}\text { Height of overground } \\
\text { sprouts. cm }\end{array}$ & 4.3 & 9.5 & 13.0 & 12.8 & 10.7 \\
\hline 4 & $\begin{array}{l}\text { Mass of vegetative over- } \\
\text { ground sprouts. g/sample } \\
\text { (wet weight) }\end{array}$ & 3.2 & 10.4 & 11.9 & 11.5 & 8.9 \\
\hline
\end{tabular}


$3.2 \mathrm{~g} / \mathrm{sample}$ (wet weight), which indicates toxicity and direct negative effect on plants. When natural mineral sorbents and peat are introduced to the drill cuttings with a norm of $15 \%$ or more, it indicates $100 \%$ germination of awnless brome with height of aboveground sprouts from 9.5 to $13.0 \mathrm{~cm}$ and high phytomass of vegetative aboveground sprouts 8 , 9-11.9 g/sample (wet weight).

\section{CONCLUSIONS}

When introducing natural mineral sorbents in different ratios in the hydro-carbon-based bore mud it was revealed that the maximal decrease of oil products concentration took place on the 7th day of the study. When introducing glauconite in a form of flour and grains it was noted that the size of sorbent seed particles insignificantly influenced the decrease of the oil products concentration in the bore mud, the best indices were found on the 28th day and made up from 47 to $66 \mathrm{mg} / \mathrm{kg}$ under different rules of introduction. The introduction of natural mineral sorbents and peat into the bore mud fa-vorably affects the development of plants, while viable phytocenosis is formed with high values of the phytomass of vegetative overground sprouts. On the basis of the studies, it was revealed that different rates of application of sorbents and peat in the hydrocarbon-based bore mud, equally well reduced the concentration of oil products. Therefore, the recommended dose of sorbents and peat at low initial values of oil products can be $3-5 \%$.

\section{REFERENCES}

1. Belov P.S., Golubeva I.A., Nizova S.A. Ecology of the production of chemical products from oil and gas hydrocarbons: a textbook for universities. 1991.

2. Bulatov A.I., Makarenko P.P., Shemetov V.Yu. 1997. Environmental protection in the oil and gas industry, 292-311.

3. Golubev E.V. Soromotin A.V. 2010. Composition and properties of drilling cuttings from Western Siberia. World of science, culture, education, 6 (25), 27.

4. Gridin O.M., Arens V.Zh., Gridin A.O. 2000. To measure seven times. Advertising illusions and real prospects for the use of oil sorbents. Oil and gas vertical, 9, 28-32.

5. Kornev V.A., Rybakov Yu. N. 2015. Mineral powdery sorbents of the bentonite type to eliminate spills of liquid oil products in the fuel pumping and storage areas. Problems of Modern Science and Education, 79-83.

6. National Standard 12038-84. Agricultural seeds. Methods for determination of germination. 2019.

7. Ovchinnikov V.P., Aksenova N.A., Grosheva T.V., Rozhnikova O.V. 2013. Modern compositions of drilling agents. Tyumen State University of Oil and Gas, 156.

8. Ryadinsky V.Yu., Deneko Yu.V. 2004. Composition and properties of drilling cuttings from Western Siberia. Bulletin of the Tyumen State University. Socio-Economic and Legal Studies, 3, 51-55.

9. Ryazanov A.Ya. 2005. Encyclopedia of drilling agents.

10. Uzbekov F.M., Molotovilova L.V., Mokhov A.E., Sokolov S.A. 2003. De-toxicization of waste drilling agent and bore mud and their disposal as reclamants in the reclamation of disturbed soils. Environmental Protection in the Oil and Gas Complex, 5, 425-429.

11. Vadetsky Yu. V. 2003. Drilling of oil and gas wells, 133-161. 